\title{
Journal of Agrometeorology
}

ISSN : 0972-1665

Vol. No. 24 (1) : 117-119 (March 2022)

https://journal.agrimetassociation.org/index.php/jam

\section{Short Communication}

\section{Water and nutrient requirement in soilless cultivation of tomato (Solanum lycopersicum $L$ ) under protected conditions in temperate region of India}

\section{SHAKEELAHMAD BHAT ${ }^{1}$, ROHITASHW KUMAR ${ }^{* *}$, J.N. KHAN ${ }^{1}$, S.A.MIR ${ }^{2}$, D. RAM ${ }^{3}$ and KURSHEED HUSSAIN $^{4}$}

${ }^{1}$ College of Agricultural Engineering and Technology, SKUAST of Kashmir, Srinagar, India

${ }^{2}$ Division of Statistics, SKUAST of Kashmir, Srinagar, India

${ }^{3}$ Division of Soil Science, SKUAST of Kashmir, Srinagar, India

${ }^{4}$ Division of Vegetable Science, SKUAST of Kashmir, Srinagar, India

*Corresponding author email : rohituhf@,rediffmail.com

Tomato crop (Solanum lycopersicum L) is one of the world's ten most significant vegetables, with around 100 MT of fresh tomato fruits production each year. Several mathematical models are available to compute the reference evapotranspiration $\left(\mathrm{ET}_{0}\right)$ using different meteorological parameters (Mehta and Pandey, 2015; Bhavsar and Patel, 2016). The crop coefficient $\left(\mathrm{K}_{\mathrm{c}}\right)$ value indicates crop-specific water usage and is essential for accurate water requirement demand for various crops cultivated in various climatic regions (Doorenbos and Pruitt, 1977).

Reference evapotranspiration (ETo) has relation between the energy and water cycles, and it is the primary source of water vapor in the atmosphere (Salam and Islam, 2020). It regulates the quantity of water needed for vegetation development, runoff, loss of water for water bodies, and water requirements for ecological sustainability. As a result, it's one of the most significant hydro meteorological factors for irrigation and water resource management, as well as ecological monitoring (Pour et al., 2020; Farooq et al., 2021). Climate variability has an influence on the hydrological cycle, particularly evapotranspiration (ET) and soil moisture, which are important factors in determining water movement in soil (Srivastava et al., 2017). These changes have major implications for management of irrigation and crop production (Bhat et al., 2017).

Soilless cultivation is one of the most important aspects of long-term protected cultivation of vegetables. Nutrient reuse after nutrient replenishment, can minimize water and fertilizer use as well as environmental contamination, which are commonly linked with over-irrigation (Stanghellini et al., 2005).In future, cultivation in open field is not possible to feed the growing population without increasing agricultural production and hence the soil-less culture is becoming more relevant in the present scenario, to cope-up with challenges of food security and sustainability.

The field experiment in soilless cultivation on tomato (Golden-600 hybrid variety) crop was conducted under poly house condition at experimental farm of Sher-e- Kashmir University of Agricultural Sciences and Technology of Kashmir, Srinagar, India. The study area located between $32^{\circ} 17^{\prime}$ and of $37^{\circ} 5$ North latitudes and $73^{\circ} 26^{\prime}$ and $80^{\circ} 30^{\prime}$ and $81^{\circ}$ East longitudes with elevation of 1500 $\mathrm{m}$ amsl The gothic type naturally ventilated poly house of $15 \times 8 \times 3 \mathrm{~m}$ size was used for crop production. The coco-peat one meter length slab was used to grow tomato crop. The average monthly weather data $\left(\mathrm{T}_{\max }, \mathrm{T}_{\text {min }}, \mathrm{RH}\right.$, sunshine hours $(\mathrm{S})$ and rainfall $\left.(\mathrm{R})\right)$ for the year 2019 was collected from the Agro Meteorological Field Unit of University situated around $350 \mathrm{~m}$ away from the field experiment.

\section{FAO-56 Penman-Monteith method (P-M)}

The FAO56 Penman-Monteith method (P-M) is widely used for reference evapotranspiration $\left(\mathrm{ET}_{0}\right.$ ) estimation (Allen et al., 1998).

$\mathrm{ET}_{\mathrm{o}}=\frac{0.408 \Delta\left(\mathrm{R}_{\mathrm{n}}-\mathrm{G}\right)+\gamma \frac{900}{\mathrm{~T}_{\text {mean }}+273} \mathrm{U}_{2}\left(\mathrm{e}_{\mathrm{s}}-\mathrm{e}_{\mathrm{a}}\right)}{\Delta+\gamma\left(1+0.34 \mathrm{U}_{2}\right)}$

Where,

$R_{n}=$ the net radiation at the crop surface $\left(M^{-2} m^{-2}\right.$ day $\left.{ }^{-1}\right), G=$ the soil 
Table 1: Composition of nutrient solution used for soilless grown tomatoes in coco-peat medium

\begin{tabular}{cc}
\hline Nutrient & Nutrient in grams in 1000 liters \\
\hline NPK $(19 \%, 19 \% 19 \%)$ & 1300 \\
Calcium & 700 \\
Iron & 300 \\
Boron & 40 \\
Copper & 60 \\
Molybdenum & 150 \\
Zinc & 30 \\
Manganese & 50 \\
Magnesium & 200 \\
\hline
\end{tabular}

heat flux $\left(\mathrm{MJ} \mathrm{m} \mathrm{m}^{-2}\right.$ day $\left.^{-1}\right) ; \mathrm{T}=$ the mean daily air temperature $\left({ }^{\circ} \mathrm{C}\right)$, $\mathrm{u}_{2}$ is wind speed $\left(\mathrm{ms}^{-1}\right)$ at $2 \mathrm{~m}$ height; $\mathrm{e}_{\mathrm{s}}$ and $\mathrm{e}_{\mathrm{a}}$ are saturation and actual vapor pressure respectively $(\mathrm{kPa}) ; \mathrm{e}_{\mathrm{s}}-\mathrm{e}_{\mathrm{a}}=$ is saturation vapor pressure deficit $(\mathrm{kPa}), \Delta=$ the slope vapour pressure curve $(\mathrm{kPa}$ $\left.{ }^{\circ} \mathrm{C}^{-1}\right) \gamma=$ the psychrometric constant $\left(\mathrm{kPa}{ }^{\circ} \mathrm{C}\right), \quad \mathrm{LAI}=$ leaf area index $\left(\mathrm{m}^{2} \mathrm{~m}^{-2}\right), \mathrm{VPD}=$ vapor pressure deficit $(\mathrm{kPa}), \mathrm{K}=$ hydraulic conductivity of the soil $\left(\mathrm{LT}^{-1}\right) ; \mathrm{Cp}=$ air specific heat at constant pressure $\left(\mathrm{MJkg}^{-1} \mathrm{C}^{-1}\right), \mathrm{r}_{\mathrm{a}}=$ aerodynamic resistance $\left(\mathrm{sm}^{-1}\right), \mathrm{r}_{\mathrm{c}}=$ canopy resistance $\left(\mathrm{sm}^{-1}\right)$

\section{Stanghellini equation}

The Stanghellini equation (Stanghellini,2005) was used to evaluate the reference evapotranspiration inside the polyhouse.

Table 2: Reference evapotranspiration (ETo), crop evapotranspiration (ETc) and irrigation requirement (IR) of soilless grown tomato crop inside and outside of polyhouse in different month during crop growth stages

\begin{tabular}{|c|c|c|c|c|c|c|}
\hline \multirow[t]{2}{*}{ Month (s) } & \multicolumn{2}{|c|}{$\mathrm{ET}_{0}(\mathrm{~mm} /$ day $)$} & \multicolumn{2}{|c|}{$\mathrm{ET}_{\mathrm{c}}(\mathrm{mm} /$ day $)$} & \multicolumn{2}{|c|}{ Irrigation requirement (IR) $(\mathrm{mm} /$ day $)$} \\
\hline & polyhouse & Outside) & polyhouse & Outside & polyhouse & Outside \\
\hline April & 2.65 & 2.59 & 0.42 & 0.76 & 0.31 & 0.76 \\
\hline May & 3.75 & 3.29 & 0.99 & 1.11 & 0.59 & 1.11 \\
\hline June & 4.59 & 3.68 & 1.57 & 1.87 & 1.42 & 1.87 \\
\hline July & 4.79 & 4.09 & 1.83 & 2.65 & 1.73 & 2.65 \\
\hline August & 3.41 & 3.30 & 1.24 & 1.85 & 0.77 & 1.85 \\
\hline
\end{tabular}

$$
\mathrm{ET}_{\mathrm{o}}=\frac{2 \mathrm{LAI}\left\{\Delta\left(\mathrm{R}_{\mathrm{n}}-\mathrm{G}\right)+\mathrm{Ki} \text { VPD.p.Cp }\right\}}{\lambda \overrightarrow{\mathrm{ra}}}
$$

Crop evapotranspiration was estimated inside the polyhouseusing the simplified Penman-Monteith equation

$$
\mathrm{ET}=\mathrm{a}[1-\mathrm{EXP}(-K \mathrm{LAI})] R_{i, g+} \beta(L A I) V P D
$$

Where $\mathrm{Kt}=$ time unit (conversion factor) that is equal to $86,400 \mathrm{~s}$ day $^{-1}$

$$
\begin{aligned}
& a=\frac{1}{\lambda}\left(\frac{\Delta+\gamma}{\Delta}\right) \\
& \beta=\frac{1}{\lambda}\left(\frac{\mathrm{Kt} \rho \mathrm{Cp}}{\mathrm{ra}} / \Delta+\lambda\right)
\end{aligned}
$$

The crop coefficient is the ratio of reference crop evapotranspiration to the crop evapotranspiration. The crop water requirement was determined using the values of $\mathrm{K}_{\mathrm{c}}$ throughout various growth phases, such as the initial stage, development stage, mid stage, and late-season stage.

$\mathrm{ET}_{\mathrm{c}}=\mathrm{ET}_{\mathrm{o}} \mathrm{x} \mathrm{Kc}$

The difference between crop evapotranspiration and effective rainfall is the irrigation demand.

Irrigation requirement $=$ crop water requirement- Effective Rain

The evapotranspiration was calculated on daily basis and then summed for different stages of growth and total water requirement of the tomato crop. The effective rain was calculated from Cropwat software. The composition of nutrient solution used for soilless grown tomatoes in coco -peat medium is given in Table 1.

\section{Water and nutrient use effieciency}

The water and nutrient use effieciency of tomato crop in soilless medium was determined. The water use effieciency (WUE) is the ratio of yield of crop $\left(\left(\mathrm{kg} \mathrm{ha}^{-1}\right)\right.$ and total water applied in $\mathrm{mm}$. The nutrient use efficiency (NUE) is the ratio of Yield $(\mathrm{Kg})$ and total fertilizer applied $(\mathrm{Kg})$.

Computation of ETand nutrient and water use efficiency of was determined in the study. The comparison of monthly reference evapotranspiration (ET), Crop evapotranspiration (ETc) and Irrigation requirement (IR) for soilless tomato crop inside polyhouse and open field condition is presented in Table 2. The reference evapotranspiration for polyhouse and open field was maximum in the month of July having values of $4.79 \mathrm{~mm} /$ day and $4.09 \mathrm{~mm} /$ day, respectively. The lowest value reference evapotranspiration was recorded in the month of April having values $2.65 \mathrm{~mm} /$ day and 2.59 $\mathrm{mm} /$ day. The growth stage wise crop water requirement (CWR) and irrigation requirement (IR) of soilless grown tomato crop in polyhouse was also determined. Inside polyhouse CWR is equal to IR because effective rainfall is considered zero. In the greenhouse, it can be seen that during initial stage crop water requirement was $22.8 \mathrm{~mm}$, during development stage was $51.4 \mathrm{~mm}$, mid stage it was $102.7 \mathrm{~mm}$ and during late-season stage, it was $57.1 \mathrm{~mm}$. In the greenhouse, the total CWR throughout the growing season was $234.0 \mathrm{~mm}$ and The CWR was maximum $102.7 \mathrm{~mm}$ during mid stage.

The CWR outside the greenhouse was maximum (72.95 $\mathrm{mm}$ ) during mid stage. The stage wise IR also showed that during initial stage it was $9.3 \mathrm{~mm}$, during development stage it was 27.8 $\mathrm{mm}$, mid stage it was $69.6 \mathrm{~mm}$ and during late-season stage was $51.6 \mathrm{~mm}$. The difference between CWR and IR is due to effective rain and the difference was maximum during late-season stage due 
to maximum effective precipitation in outside poly house. The total effective rain over the entire cycle was $13.9 \mathrm{~mm} / \mathrm{Dec}$. The total irrigation requirement and total crop water requirement for the tomato crop outside was found to be $158.3 \mathrm{~mm} / \mathrm{dec}$. and $172.4 \mathrm{~mm} /$ dec, respectively. The maximum IR $(19.3 \mathrm{~mm} / \mathrm{dec})$ and maximum CWR (20.05) were found during mid stage.

Drip irrigation levels had a favorable and significant effect on WUE and NUE in tomato. The WUE of tomatoes grown in soilless media is about $250 \mathrm{~kg} / \mathrm{ha}-\mathrm{mm}$. Whereas NUE is $110 \mathrm{~kg}$ yield $/ \mathrm{kg}$ nutrient. The data on fruit yield per plant in soilless culture shows that in greenhouse conditions. The fruit yield of each plant inside the polyhouse was about $13.1 \mathrm{~kg} /$ plant where as outside polyhouse it was $4.6 \mathrm{~kg} /$ plant.

In this study soilless media was evaluated inside polyhouse and in open field conditions and compared them in terms of evapotranspiration, water requirement, irrigation scheduling, water use efficiency, nutrient use efficiency and yield of tomatoes for the decision-making processes. The total crop water requirement (ETc) of soilless grown tomatoes in the greenhouse was found to be $234.0 \mathrm{~mm}$. The total irrigation requirement and total crop water requirement $(\mathrm{ETc})$ of the tomato crop gown outside was found to be $158.3 \mathrm{~mm}$ and $172.4 \mathrm{~mm}$, respectively. The fruit yield of each plant inside the polyhouse was about $13.1 \mathrm{~kg} /$ plant where as outside greenhouse it was $4.6 \mathrm{~kg} / \mathrm{plant}$. So, growing of crops in the soilless media in the polyhouse gives the better yield both in terms of quality and quantity and can be used in the future to overcome the food demand.

\section{ACKNOWLEDGMENTS}

Authors are highly grateful to the ICAR-All India Coordinated Research Project on Plastic Engineering in Agriculture Structures and Environment Management, COAE\&T, SKUAST-K, Srinagar for providing the required facilities for the study's completion.

Conflict of Interest Statement: The author (s) declares (s) that there is no conflict of interest.

Disclaimer: The contents, opinions and views expressed in the research article published in Journal of Agrometeorology are the views of the authors and do not necessarily reflect the views of the organizations they belong to.

Publisher's Note: The periodical remains neutral with regard to jurisdictional claims in published maps and institutional affiliations.

\section{REFERENCES}

Allen, R.G., Pereira, L.S., Raes, D. and Smith, M. (1998). Crop evapotranspiration: guidelines for computing crop requirements. FAO Irrigation Drainage Paper No. 56, FAO: Rome; 300 .

Bhat, S.A., Pandit, B., Dar, M.U.D., Ali, S.R., Jan, R. and Khan, S. (2017). Comparative study of different methods of evapotranspiration estimation in Kashmir Valley.J. Agrometeorol., 19(4): 383-384.

Bhavsar, P.N. and Patel, J.N. (2016).Development of relationship between crop coefficient and NDVI using geospatial technology.J. Agrometeorol., 18(2): 261-264.

Doorenbos, J. and Pruitt, W.O. (1977). Guidelines for predicting crop water requirements. Irrig. Drain Paper24 (revised) Food and Agricultural Organization of the United Nations, Rome.

Farooq,Z., Kumar, R., Singh, V.P. (2021) Trend of reference evapotranspiration under climate change in Himalayan region, India .J. Agrometeorol., 23 (1): 127-131

Mehta, R. and Pandey, V. (2015). Reference evapotranspiration (ETo) and crop water requirement (ETc) of wheat and maize in Gujarat. J. Agrometeorol., 17(1).107-113.

Pour, S. H.,Wahab, A.K.A., Shahid, S., Ismail, Z.B. (2020) Changes in reference evapotranspiration and its driving factors in peninsular Malaysia. Atmos Res: 105096

Salam R, Islam A.R.M.T. (2020). Potential of RT, Bagging and RS ensemble learning algorithms for reference evapotranspiration prediction using climatic data-limited humid region in Bangladesh. J. Hydrol, 590:125241.

Srivastava, P.K., Singh, P., Mall, R.K., Pradhan, R.K., Bray, M. and Gupta, A. (2020). Performance assessment of evapotranspiration estimated from different data sources over agricultural landscape in Northern India. Theo. App. Climatol., 140: 145-156.

Stanghellini, C., Kempkes, F., Pardossi, A., Incrocci, L. (2005). Closed water loop in greenhouses: effect of water quality and value of produce.ActaHortic. 691, 233-241. 